\title{
Subject Characteristics Test
}

National Cancer Institute

\section{Source}

National Cancer Institute. Subject Characteristics Test. NCI Thesaurus. Code C83149.

A character or string that represents the full name of the subject characteristics assessment. 